\section{Mr. H. Chapman Jones}

THE death of Henry Chapman Jones on March 7, at the age of seventy-seven years, removed one who has held an honourable place in the teaching of chemistry and in the development of the science and practice of photography. Apart from an early association with Birkbeck College, Chapman Jones's career as a teacher of chemistry was bound up with the Royal College of Science, where he was successively assistant, demonstrator, and lecturer, from 1881 until 1914, when he retired. In the first few years of this long period he was on Sir Edward Frankland's staff, and later he served under T. E. Thorpe, W. A. Tilden, and H. B. Baker. For a number of years he presided over the North Labora. tory in the old Royal College of Science buildings, and many who worked there will recall the quiet, serious, and kindly way in which he went about his duties, as well as the high standard of industry and accuracy which he expected of his students.

The main contributions to knowledge made by Chapman Jones were in the domain of photography, and were published principally under the auspices of the Royal Photographic Society. Following Sir William Abney in the application of scientific method to the problems of photography, Chapman Jones dealt with such matters as the densities of negatives, the factors affecting the sensitiveness of plates, media of high refractive power for photomicrography, and the relationship between the size of the particle and the colour of the image.

Besides original papers on these and other topics, Chapman Jones contributed many articles on photographic subjects to the technical press, while two books on photography came from his pen, namely, "Science and Practice in Photography", which ran to four editions, and "Photography of To-day ", a popular treatise published in 1913. His associations with the Royal Photographic Society were very close, and after being honorary secretary from 1892 until 1897, and vice-president from 1897 until 1902, he became president of the Society in 1912. In addition, he was a fellow of the Chemical and Physical Societies and of the Institute of Chemistry.

Chapman Jones was a single-minded man, whose integrity and ideals were of the highest. His quiet, almost shy, old-world courtesy and his modesty were marks of an interesting personality which only those who knew him well could appreciate. At the same time, he held strong opinions on many subjects, and he did not hesitate to express these in his own direct, unimpassioned way. His gentle, warmhearted nature revealed itself to best advantage in the circle of his own family and of those who knew him intimately. He is survived by a widow and two sons.

J. C. P.

\section{Dr. Michael Perkins}

Michael Gerard Laurence Perkins died, following an attack of scarlet fever which developed apparently into a general septicæmia, on March 14, at thirty-three years of age. Perkins was educated at St. Peter's College, Westminster; King's

$$
\text { No. 3259, VoL. 129] }
$$

College, London ; and Trinity College, Cambridge. He was Huxley Prizeman at King's College and a Senior Scholar of Trinity. He was elected to the Mackinnon Research Studentship of the Royal Society in 1925. He took his M.A. in 1926, his Ph.D. in 1930, and joined the Westminster Hospital Medical School in 1927.

Michael Perkins had many interests, his greatest love being that of natural history. He had a keen intelligence, a vivid imagination, and boundless enthusiasm and energy - qualities which might have earned him a prominent place in the ranks of science. He published work on the Coleoptera of Guernsey and Wicken Fen, on Cambridgeshire Planarians, and, becoming interested in the Crustacea, published in 1928 a simple key to the crabs (Brachyura) of Britain and the north-eastern Atlantic. His own observations on local varieties of a species of Platyhelminthe worm, of which the peculiarities seemed to be correlated with slight changes in environment, led him to take an active interest in the work of the late Dr. Kammerer. It was partly through the influence of Perkins that Kammerer was invited by the Cambridge Natural History Society (of which Perkins had been secretary for two years) to demonstrate his specimens and to discuss his much-disputed experiments. Perkins' interest in the problems of parasitism brought him into touch with the remarkable sex change induced in crabs by Sacculina, a phenomenon which he studied from the biochemical point of view in Cambridge (see NATURE, 124, 299 ; 1929). He was also engaged upon work on the respiratory metabolism of bats.

Perkins' work was perhaps marred by the diversity of his interests, his restless mind preventing that concentration necessary for the successful completion of a single piece of work. Time, however, was steadying him, and there is much that is valuable in the mass of unpublished data left by him.

Perkins' lovable nature was his chief characteristic ; his ready optimism, his wit, and his profound knowledge of a multitude of subjects, ranging from folklore to mystery plays, won him innumerable friends and made him a most agreeable and interesting companion. His boundless energy and zeal were ever at the service of others. His early death has come as a great shock to all who knew him and loved him so well. There are many who will sympathise with his bereaved parents in their great loss.

J. H. Q.

WE regret to announce the following deaths:

M. Guillaume Bigourdan, president in 1924 of the Paris Academy of Sciences and formerly director of the Bureau International de l'Heure, on Feb. 28, aged eighty years.

Dr. R. M. Brontë, pathologist to the Home Office and formerly Crown Analyst in Ireland, on March 22, aged fifty-two years.

Prof. Wilhelm Ostwald, emeritus professor of chemistry in the University of Leipzig, Nobel prizeman in chemistry for 1909, and an honorary fellow of the Chemical Society, on April 4, aged seventy-eight years. 